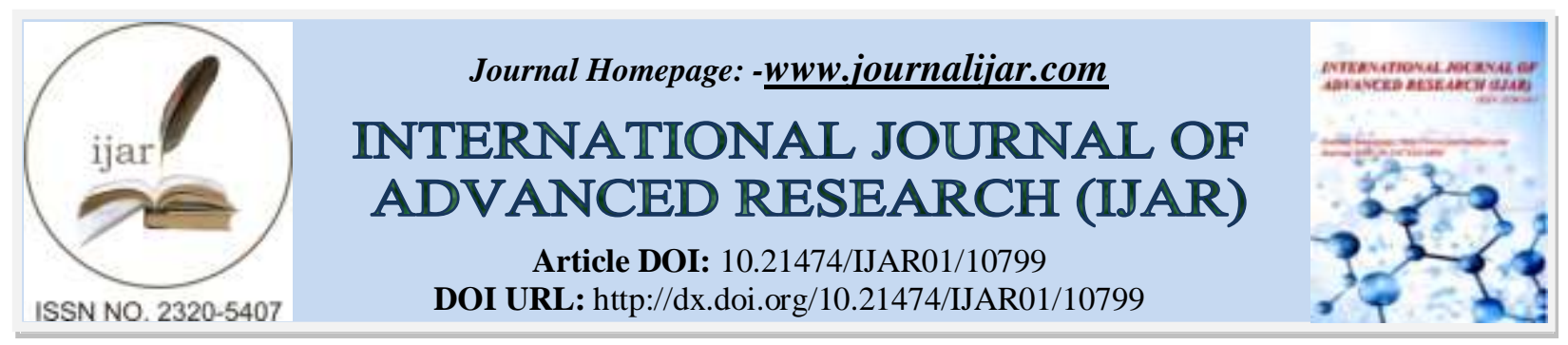

RESEARCH ARTICLE

\title{
PHYSICO-CHEMICAL ANALYSIS OF WATER BODY OF DEHRADUN
}

Vandana Tewari and Deepak Kumar Mittal

Department of Zoology,Sri Satya Sai University of Technology and Medical Sciences, Sehore.

\section{Manuscript Info}

Manuscript History

Received: 10 February 2020

Final Accepted: 12 March 2020

Published: April 2020

Key words:-

Physico-Chemical Parameters,

Sahastradhara, Correlation

\section{Abstract}

This study is emphasis on physico-chemical parameter of Sahastradhara in Dehradun.During the present study various physicochemical parameters viz. water temperature, $\mathrm{pH}$, turbidity total solids, totaldissolved solids, total suspended solids, dissolved oxygen, Conductivity, total alkalinity; total hardness, calcium,magnesium, chlorides etc. were analyzed. The result shows the significance correlation in different parameters thatindicate the water quality of lake water. It was observed that physico-chemical parameters were fluctuated due tocertain anthropogenic activities and seasonal variation.

Copy Right, IJAR, 2020,. All rights reserved.

\section{Introduction:-}

Water is one of the most abundant compoundsfound in nature covering approximately three-fourthsof surface area of the earth. On the earth surface $50.01 \%$ of water is available in lake (Beebi et al.,2004). Lake are intangible resources create differentopportunity in socio-economic development ofconcern area. Sahastradhara are play the very important role inecosystem for sustain a healthy balance aquatic lifeand recharge of ground water, conserve soil nutrient,and support our socio-economic requirements. Theaccent time human being uses of lake water in variousways like drinking, agriculture, domestic, raring of fishetc. Today anthropogenic activities and humaninterference affects the lake water quality. In day byday process degraded water quality directly orindirectly, its impact on aquatic life. Therefore, it isnecessary continuous assessment of physical,chemical \& biological parameter of water forconservation of lake heath. Sahastradhara Dehradun famous for scenic beauty \& fishculture. It is experience that this lake polluting day byday due to certain activities in catchment area.

\section{Material And Methods:- \\ Study Area:}

Dehradun district is situated in NW corner of theUttarakhand state and extends from N Latitude $29^{\circ} 58^{\prime \prime}$ to $38^{\circ} 30^{\prime}$ and E Longitude $77^{\circ} 34^{\prime} 45^{\prime \prime}$ to $78^{\circ} 18^{\prime} 30$. The Doon valley covered by two main River. In the eastern side Ganga river flowing and westernside Yamuna river. It is famous for many intangibles.Following physico-chemical parameters were analysis of lake water with the help of Standard methods of APHA (2001).

1. Temperature

2. $\mathrm{PH}$

3. Turbidity

4. Conductivity

5. Total Solids

6. Total Dissolved Solids 
7. Total Suspended Solids

8. Dissolved Oxygen

9. Total Alkalinity

10. Total Hardness

11. Calcium

12. Magnesium

13. Chlorides

\section{Study site:}

Sahastradhara is situated in district, Dehradun. This lake is known for its Scenic beauty and fishery culture. During one year of study period viz. October 2018 to September 2019, monthly data presented seasonally. The area of Sahastradhara is about $4500 \mathrm{~m} 2$. The catchment area of lake covered by market, Road, Small Patches of forest area Drainage system. This lake is also habitat for many migratory and native birds. This lake is famous for boating and habitat for various fish species like Catla catla, Silver carp, and Labeo sp. etc.

\section{Result and Discussion:-}

The Average SD values of water physico-chemical parameters or correlation analysis are discussed below and also presented in the Table- 1 .

Table-1:- The average SD value of seasonal variation of physico-chemical parameter of Sahastradhara, Dehradun.

\begin{tabular}{|l|l|l|l|}
\hline S. No & Physico-chemical parameter & Post Monsoon & Pre Monsoon \\
\hline 1. & Air Temp.(0C) & $24.27 \pm 0.422$ & \\
\hline 2. & Water Temp.(0C) & $22.97 \pm 0.0518$ & $38.2 \pm 0.36$ \\
\hline 3. & PH & $8.00 \pm 0.03304$ & $26.075 \pm 0.095$ \\
\hline 4. & Turbidity (NTU) & $14.0 \pm 2.29$ & $8.26 \pm 0.056$ \\
\hline 5. & Conductivity (Umho/cm) & $8.49 \pm 1.45$ & $19.74 \pm 0.467$ \\
\hline 6. & Total Solids (mg/l) & $1788.5 \pm 16.17$ & $13.8 \pm 1.36$ \\
\hline 7. & Total dissolved Solids $(\mathrm{mg} / \mathrm{l})$ & $1322 \pm 8.46$ & $2079.5 \pm 22.1$ \\
\hline 8. & Total Suspended Solids $(\mathrm{mg} / \mathrm{l})$ & $466.5 \pm 10.45$ & $1565.25 \pm 9.902$ \\
\hline 9. & Total Alkanity (mg/l) & $292.72 \pm 15.36$ & $542.4 \pm 12.1$ \\
\hline 10. & Total Hardness (mg/l) & $260.16 \pm 18.93$ & $306.84 \pm 11.7$ \\
\hline 11. & Calcium $(\mathrm{Ca}++)(\mathrm{mg} / \mathrm{l})$ & $55.22 \pm 6.85$ & $350.7 \pm 25.8$ \\
\hline 12. & Magnesium(Mg+2)(mg/l) & $30.12 \pm 4.91$ & $40.9 \pm 2.52$ \\
\hline 13. & Chloride Cl- $(\mathrm{mg} / \mathrm{l})$ & $55.22 \pm 8.94$ & $35.5 \pm 5.79$ \\
\hline
\end{tabular}

\section{Water Colour:}

The colour of lake water is related to the type and amount of dissolved organic Chemicals. The colour show the aesthetic value, it influence light penetration or affected the planktonic growth and process of photosynthesis. Color of lake water is related to the type and amount of dissolved organic chemicals (Shaw et al., 2004). At the present study the green colour of lake water was observed in post monsoon and it is mainly due to the algal growth.

\section{Temperature:}

Water temperature plays the Negative or Positive effect on water quality parameter and aquatic diversity (Colman et al., 1992). The bacterial activities decomposed the organic matter, changed into lake nutrients which are affected by temperature (Entz, 1972). The average SD value of Water temperature in golden lake ranged between $22.98 \pm 0.051$ and 26.07 \pm 0.09 during Post monsoon and Pre monsoon respectively. The most suitable temperature for plant growth is $20^{\circ} \mathrm{C}$ to $35^{\circ} \mathrm{C}$ (Patil, et al., 2011). Similarly, Bhadula and Joshi (2012) studied on impact of sewer drain and find out that high temperature of water body due to anthropogenic activities. They further pointed out that water temperature is responsible for metabolic activities of aquatic milieu. During the study time positive correlation with different parameter such as total alkalinity, total hardness, chloride etc. 
pH:

During the whole study period lake water show the alkaline in nature. The ranged of PH were observed between $8.26 \pm 0.056$ to $8.00 \pm 0.03$ Pre monsoons \&Post monsoon respectively. The high value of PH may be due to attributed with catchment area. The PH ranged is 5.00-8.5 good for planktonic growth (Umavathi et al., 2007; Chisty 2002). At the study time PH was positive correlation with TDS, TSS, DO, Total Alkalinity, Total Hardness, Chlorides (Gupta et al., 2009). Mulongaibalu (2014) was found the strong positive correlation between DO and PH in River or Lake Water.

\section{Turbidity:}

Turbidity is another very important parameter of lake water quality, it measured by Nephelometric method. Turbidity caused by suspended particulate matter and dissolved organic matter (Shaw et al., 2004). In the present study period value of lake water turbidity ranged from 19.74 \pm 0.46 to $14.0 \pm 2.29$ NTU (Table-1) Pre monsoon and Post monsoon respectively. High turbidity observed in summer may be due to low water table and high rate of decomposition of organic matter. Mohamed, (2009) observed the high turbidity during in summer (116 NTU). Bhadula and Joshi (2011) studied on major and minor canal of Ganga river and pointed out that physico-chemical parameters were degraded due to manmade activities in minor canal of Ganga river at Haridwar. They further added that turbidity was higher in minor canal due to dumping of solid waste and formation of algal bloom. Electrical conductivity: During the present study time the maximum $(13.8 \pm 1.36 \mathrm{Umho} / \mathrm{cm}) \mathrm{EC}$ was noted in Pre monsoon and minimum $(8.49 \pm 1.45 \mathrm{Umho} / \mathrm{cm})$ in Post monsoon. At the study time the Electrical Conductivity shows significant positive correlation with the TS, TDS, total hardness, calcium, magnesium of water (Mohamed, 2009; Patil. et al, 2012).

\section{TS, TDS \& TSS:}

During the investigation period the maximum value of TS, TDS, TSS were found 2079.5 $\pm 22.1,1565 \pm 9.90,542.4 \pm$ $12.1 \mathrm{mg} / \mathrm{l}$ respectively in post monsoon season may be due to low water table (Rai \& Singh 2006). The minimum value of TS, TDS \& TSS recorded in Pre monsoon. The minimum values are 1788.2 $\pm 16.17,1321 \pm 8.46 \&$ $466.1 \pm 10.45 \mathrm{mg} / \mathrm{l}$ respectively may be due to effect of rain water (Verma et al., 2011). At the present study time the TS, TDS \& TSS strongly positive correlation with DO, Total Alkalinity \& chloride (Table-2). (Medudhula et al., 2012) was observed the positive correlation between TDS \&Hardness, Chloride, and Alkalinity in Manair reservoir.

\section{Dissolved oxygen:}

The dissolved oxygen is most important parameter of aquatic system. Its impact on water body directly or indirectly in different activity such as bacterial, photosynthesis, availability of nutrients, stratification etc (Vikal, 2009). At the present study time the maximum average value $(6.3 \pm 0.11 \mathrm{mg} / \mathrm{l})$ was recorded in Post monsoon and minimum value $(5.1 \pm 0.51 \mathrm{mg} / \mathrm{l})$ in Pre-monsoon. The minimum value of DO was found in pre monsoon season may be due to increase temperature and high Bacterial activity for decomposition of organic matter (Kataria, 1996; Korium, \& Toufeek, 2008). During the study time DO show the direct correlation with PH due to during mineralization, decomposition of organic matter release humic acid that' by its effect on

PH level (Lowe-McConnell, 1987). Bhadula and Joshi (2014) have studied on impact of touristic activities on environmental parameters of Ganga river and illustrated that Dissolved oxygen showed negative correlation with temperature.

\section{Total Alkalinity:}

Total Alkalinity means combination of carbonate (CO3 2-), bicarbonate (HCO3-) \&hydroxyl ions. Total alkalinity in lake water was direct affected by soil sedimentation minerals, water level \& catchment area (Shaw et al., 2004). During the present study time the maximum value of Total alkalinity was noted $306.84 \pm 11.73 \mathrm{mg} / \mathrm{l}$ in Pre monsoon season may be due to decrease in water level of lake (Patil 2011). The minimum total Alkalinity was $292.72 \pm 15.36$ $\mathrm{mg} / \mathrm{l}$ noted in Post monsoon. According to Maheshwari et al., 2011) the value of total Alkalinity ranged between 154 to $354 \mathrm{mg} / \mathrm{l}$ support to algal growth and other aquatic life.

\section{Total hardness, Calcium and Magnesium Hardness:}

In the study time the maximum value $350.07 \pm 25.8 \mathrm{mg} / \mathrm{l}$ of Total hardness was noted in Pre monsoon season due to low water table (Patil.S.G.2011). The minimum value of total hardness was found $260.16 \pm 18.93 \mathrm{mg} / 1 \mathrm{in}$ Post monsoon season may be due to runoff rain water in lake (Khan. et al., 2012). During the present study time value of Calcium range varies between $57.23 \pm 10.04 \mathrm{mg} / \mathrm{l}$ to $55.22 \pm 6.85 \mathrm{mg} / \mathrm{l}$ in Pre monsoon and Post Monsoon 
respectively. According to Kaiwal et al., (2003) the presence of calcium in water is more likely in the form of carbonate, it indicates the high value of hardness. The range of magnesium was noted $40.9 \pm 2.52$ to $30.12 \pm 4.91 \mathrm{mg} / \mathrm{l}$ in Pre monsoon and Post monsoon respectively. At present study time significant correlation with different parameter such as Water temperature, Total Alkalinity, Total Suspended Solid.

\section{Chlorides:}

During the present study time Chlorides ranged varies between $55.22 \pm 8.94 \mathrm{mg} / \mathrm{l}$ to $35.5 \pm 5.79 \mathrm{mg} / \mathrm{l} \mathrm{Post} \mathrm{monsoon}$, Pre monsoon respectively. Umavathi et al. (2007) showed that higher concentration of chloride is association with increased level of pollution. At present study time Chloride show significant correlation with different parameter such as Water temperature, PH, Total Dissolved Solid, DO. Medudhula, et. al (2012) observed the significance correlation in same parameter in Manair reservoir.

\section{Conclusion:-}

The result revealed that there was significant seasonal variation in some physico-chemical parameters and most of the parameters were in the normal range and indicates better quality of lake water. This lake is famous for fish culture various fishes found in this lake like Rohu, Catla catla etc. Therefore, there is urgent need to conserve lake, and aware the people for protection of natural lake water.

\section{Acknowledgement:-}

The author extremely thankful to my supervisor for guidance to this type of research work and department of Zoology for providing all facilities in laboratory.

\section{References:-}

1. APHA. Standard methods for the examination of water \& waste water .port city press, Baltimore, Maryland, USA. Ed. 2001.

2. Maheshwari, A. Sharma, M. and Sharma, D. (2011): Hydro Chemical Analysis of Surface and Ground Water Quality of Yamuna River at Agra, India. J. Mater. Environ. Sci. 2011; 2 (4) (2011) 373-378.

3. Beebi, S.K., Dadhich, A.S. and Arunakranti, P. Monitoring the status of water resources of Srungavarapukota village area in Andra Pradesh. Nature Environment and Pollution Technology, 2004; 3(3), 303-306.

4. Bhadula, S and Joshi, B.D. An Assessment of the impact of sewer drains on the main canal of River Ganga, within Haridwar city, Uttarakhand, India. Researcher. 2012; 4 (1): 7-14.

5. Bhadula, S and Joshi, B.D. A Comparative Study of Physico-Chemical Parameters of the Major and Minor Canals of the River Ganga within Haridwar. J. Environ. \& Bio. Sci. 2011; 25 (2): 285-290.

6. Bhadula, S and Joshi, B.D. Impact of religiotouristic activities on the environmental condition with special reference to water quality and solid waste generation within Haridwar city, India. International journal of plant, animal and Environmental Sciences. 2014; 4 (4): 309-315.

7. Khaiwal R, Ameena, Minakshi, Monika, Rani and Kaushik A. Seasonal variations in physicochemical characteristics of River Yamuna in Haryana and its ecological best-designated use, Journal of Environmental Monitoring 2003; 5, 419-426.

8. Chisty. N. Studies on Biodiversity of Freshwater Zooplankton in Relation to Toxicity of selected Heavy Metals. Ph. D. Thesis submitted to M.L Sukhadia Univeristy Udaipur. 2002.

9. Colman, J., Lardinois, P., Rabelahatra A., Rafaliarison, J., van den Berg, F. Randriamiarana, H., and Johannes, J. Manuel pours le Développement de la Pisciculture à Madagascar, FI: DP/MAG/88/005. Document Technique N4. PNUD/FAO-MAG/88/005. Antsirabe, Juillet 1992.

10. Entz, B. Report on the limnlogical conditions of Lake Nasser on the report of survey of Lake Nasser and Lake Nubia. Working paper No.6 (LNDC-RPA) Aswan, Egypt. 1974

11. Gupta, D. P., Sunita and Saharan., J. P. Physiochemical Analysis of Ground Water of Selected Area of Kaithal City (Haryana) India, Researcher, 2009; 1(2), pp 1-5.

12. Kataria, H.C, Iqbal, SA and Shandilya, A.K. Limno- chemical. Studies of Tawa Reservoir.IJEP. 1996; 16(11): 841-846.

13. Korium, M.A. and Toufeek, M.E.F. Studies of Some physicochemical characteristics of old AswanDam reservoir and River Nile water at Aswan. Egyptian. J. of aquat. Resear., 2008; 34: 149-167.

14. Lowe-McConnell, R.H., (1987): Ecological Studies in Tropical Communities. Cambridge University Press, $12+382 \mathrm{pp}$. 
15. Medudhula. Thirupathaiah, Ch. Samatha, Chintha Sammaiah. Analysis of water quality using physico-chemical parameters in lower manair reservoir of Karimnagar district, Andhra Pradesh. International Journal of Environmental Sciences. 2012; 3(1).

16. Mohamed A.F. Toufeek and Mostafa A. Korium. Physicochemical Characteristics of Water Quality in Lake Nasser Water. Global Journal of Environmental Research. 3 (3): 2009; 141-148.

17. Patil Shilpa G., Chonde Sonal Goroba, Jadhav Aasawari Suhas, Prakash D. Raut. Study of physicochemical and biological characteristics of lakes from Shivaji University Campus, Kolhapur, Maharashtra, Advances in Applied Science Research, 2011, 2 (6):505-519. 